11. Sotsialna vidpovidalnist torhivelnoi marky «Tetra» [Social responsibility of Tetra trademark]. Retrieved from https://www.facebook.com/groups/1670732199819185/?fref=ts

12. Kolota, A. M., Hrishnova, O. A. et al. (2012). In A. M. Kolot (Ed.). Sotsialna vidpovidalnist: teoriia $i$ praktyka rozvytku: monohrafiia [Social responsibility: theory and practice of development]. Kyiv: KNEU [In Ukrainian].

13. Torhivelna marka «Rikka» [Trademark https://www.facebook.com/pg/tmrikka/about/?ref=page_internal

14. Chetverta Mizhnarodna vystavka suchasnoi akvariumistyky ta terariumistyky «Akvaterra shou» [Fourth International Exhibition of Modern Aquarium and Terrarium «Akvaterra show»]. Retrieved from http://www.aquaterrashow.com.ua

Стаття надійшла до редакції 10.11.2019 р.

УДК 339.152

Makara Oksana, doctor of economics, Prof. Department of Finance and Credit, Lesya Ukrainka Eastern European National University, Lutsk, e-mail: ok302008@ukr.net

Lialiuk Alla, Associate Professor, Economics and Security of Enterprise Department, Lesya Ukrainka East European National University, Associate Professor, Ph.D. in Economics. Lutsk, ORCID ID: 0000-0002-4889-0511 e-mail: allalyalyuk@gmail.com

Panasiuk Yurii 3rd year student of the Faculty of Economics and Management, Lesia Ukrainka East European National University, Lutsk,. e-mail: yura@macaw.me

\author{
https://doi.org/10.29038/2411-4014-2019-04-116-124
}

\title{
MODERN TECHNOLOGIES OF MARKETING INTELLIGENCE
}

The purpose of the article is to explore the use of the latest technologies in marketing intelligence, and to offer a vision of its use without harming the social and physical health of consumers. The methodological basis of the research was foreign and domestic publications and analytical reviews on the problems of marketing intelligence using web analytics. The proposed approaches can be taken into account by the marketing services of domestic enterprises when conducting marketing intelligence. An example of Google Analytics examines the technology of marketing intelligence. It is concluded that the beginning of development of open methods of processing private data of users without their direct identification is positive. which would limit the interference with the privacy of people, leaving marketing intelligence possible, and would prevent its negative impact on people's lives.

Key words: marketing intelligence, site, Google Analytics, web analytics system, audience

Макара Оксана, доктор экономических наук, профессор, Восточноевропейский национальный университет имени Леси Украинки, кафедра финансов и кредита, г. Луцк 
кандидат экономических наук, доцент

Восточноевропейский национальный университет имени Леси Украинки, кафедра экономики, безопасности и инновационной деятельности предприятия г. .Луцк

Панасюк Юрий

студент 3 -го курса факультетаэкономики и управления Восточноевропейский национальный университет имени Леси Украинки г. Луцк

\section{СОВРЕМЕННЫЕ ТЕХНОЛОГИИ МАРКЕТИНГОВОЙ РАЗВЕДКИ}

Целью статьи является исследование использования новейших технологий в осуществлении маркетинговой разведки, и предложить свое видение ее использования без ущерба социальному и физическому здоровью потребителей. Методологической основой исследования стали зарубежные и отечественные публикации и аналитические обзоры по проблемам маркетинговой разведки с использованием веб-аналитики. Предложенные подходы могут быть учтены маркетинговыми службами отечественных предприятий при осуществлении маркетинговой разведки. В статье на примере системы Google Analytics проанализирована технологиия осуществления маркетинговой разведки. Сделан вывод, что положительным является начало разработки компаниями открытых методов обработки личных данных пользователей без их непосредственной идентификации. которые ограничили бы вмешательство в частную жизнь людей, оставляя возможным осуществление маркетинговой разведки, а также сделали бы ее негативное влияние на жизнь людей.

Ключевые слова: маркетинговая разведка, сайт, Google Analytics, система веб-аналитики, аудитория

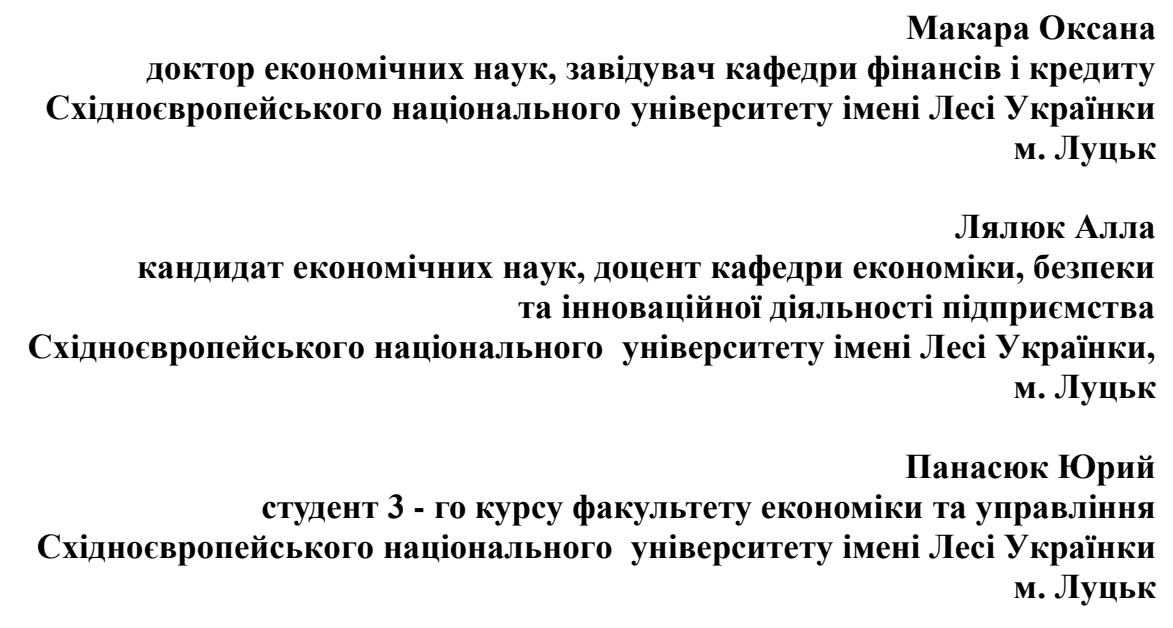

\section{СУЧАСНІ ТЕХНОЛОГІЇ МАРКЕТИНГОВОЇ РОЗВІДКИ}

У період постійних змін проведення маркетингової розвідки спрощують сучасні інформаційні технології. У статті на прикладі такої системи веб-аналітики як Google Analytics розглянуто як може сьогодні працювати маркетингова розвідка. Google Analytics дозволяє збирати статистику про поведінку користувачів на сайті i формувати на підставі отриманих даних аналітичні звіти: можна підсліджувати відвідуваність, конверсію і дохід Інтернет-просування; вивчити проблеми як самого ресурсу так і рекламних компаній в мережі та управляти ними більш ефективно. Google Analytics на основі отриманих даних 3 coоke-файлів дозволяє сформувати звіти про аудиторію насамперед за такими ознаками як демографія, інтереси, місцезнаходження, нові користувачі і повернені, періодичність і час останнього відвідування, а також звіти з огляду по мобільних пристроях, шляхи яким користувачі заходили на шлях та інші. Такий аудит дозволяє побачити слабкі сторони сайту. Отримати проміжні дані і зробити остаточні висновки про результативність тих чи інших доробок. Окрім цього, Google Analytics аналізуючи референт, визначає зміст пошукового запиту і заносить його в параметр «Ключове слово», це є підгрунтям для формування ефективної контекстної реклами. 
Незважаючи на очевидні переваги для власників сайтів від використання цієї програми виникає ряд проблем етичного характеру. Деякі компанії отримують інформацію за допомогою використання вразливості програмного забезпечення чи шляхом отримання доступу до системних сервісів телефону. Постійний збір даних під час маркетингової розвідки породжує і інші проблеми: можна легко отримати доступ до певної інформації про людину для іiі подальшого використання при шантажі з вимаганням відкупу; або легко отримати інформацію про людину просто відкривши ії браузер.

Отже, маркетингова розвідка $є$ необхідною для розроблення та коригування маркетингового плану компанії для прогнозу майбутніх змін. На жаль, сьогодні маркетингова розвідка нерідко здійснюється за допомогою методів комерційного та промислового шпигунства, що $є$ причиною моральних та правових проблем. Сьогодні в світі починають здійснюватися певні заходи щодо розробки великими компаніями безпечних та відкритих методів обробки приватних даних користувачів без їх безпосередньої ідентифікації. Перспективою подальших досліджень повинна стати розробка законодавчої бази та правил, які обмежили б втручання в приватне життя людей, залишаючи можливим здійснення маркетингової розвідки, а також, унеможливили б її негативний вплив на життя людей.

Ключові слова: маркетингова розвідка, веб-сайт, Google Analytics, система веб-аналітики, аудиторія

Formulation of the scientific problem and its significance. In times of constant change, businesses need to constantly adapt to consumers and produce the goods and services they need. That is why marketing intelligence is carried out, which is facilitated by modern information technologies. Because they are not in place, data is becoming more and more difficult every day. Therefore, there is a need to analyze and evaluate the effectiveness of the high-tech solutions used in marketing intelligence.

Analysis of recent research and publications. In the scientific literature, this problem has been raised mainly by foreign scientists, including Whittaker Z, Dance G., M. LaForgia M., Stallman R., Hunt Ch., Etc. $[3,4,8,13,17]$, however, in domestic science and practice, this phenomenon is quite new and has not been fully explored.

The purpose and objectives of the article. Investigate the using of the latest technologies in marketing intelligence; determine how the causes of underperformance are identified and how the necessary recommendations are made to improve the company's performance; identify problems that arise in this area and suggest ways to solve them.

Presentation of the main material and substantiation of the results of the research. Marketing intelligence is the activity of gathering information about changes in the marketing environment, required for development and adjust marketing plans and decisions that are constantly implemented by enterprises. The goals of marketing intelligence are partially different from the goals of marketing research. Unlike marketing research, marketing intelligence must be conducted on an ongoing basis, based on the information available, without special research. Based on marketing intelligence, companies need to conclude the need for marketing research. However, it should be noted that due to scientific and technological progress, the difference between marketing intelligence and marketing research is gradually decreasing (Fig. 1).

The goals and objectives of marketing intelligence can be included in the ongoing work of gathering information about the marketing environment. The most optimal is when different data are grouped into specific groups: competition (available information on existing and probable competitors), market (all data on the market situation, consumer needs), technology (used in the production of products), legislation (all regulatory, legal acts that affect the activity of the enterprise), resources (all data on material and technical resources that are important for the normal functioning of the enterprise), general trends in politics, economy and other areas; other factors not previously taken into account.

Today there are many different classifications of channels of receipt of information. Among them is the classification " $4 \mathrm{~K}+1$ ", which is proposed by scientists Ch. Hunt and V. Zartaryan [17]:

- «text», various publications in scientific publications and mass media, as well as various databases placed in the open access (through this channel the company receives up to $40 \%$ of intelligence);

- «firm», contains suppliers, customers, bankers, agents, etc. (30-40\% of information);

- «consultant» - public services and consultants (10-15\%);

- «conversation» - conferences, fairs, presentations (5-6\%);

- «joker» $(+1)$ complements the amount of intelligence. Usually, this is random information, rumors. They also use a different classification of channels: media, data banks, staff, channel «X» [1]. 


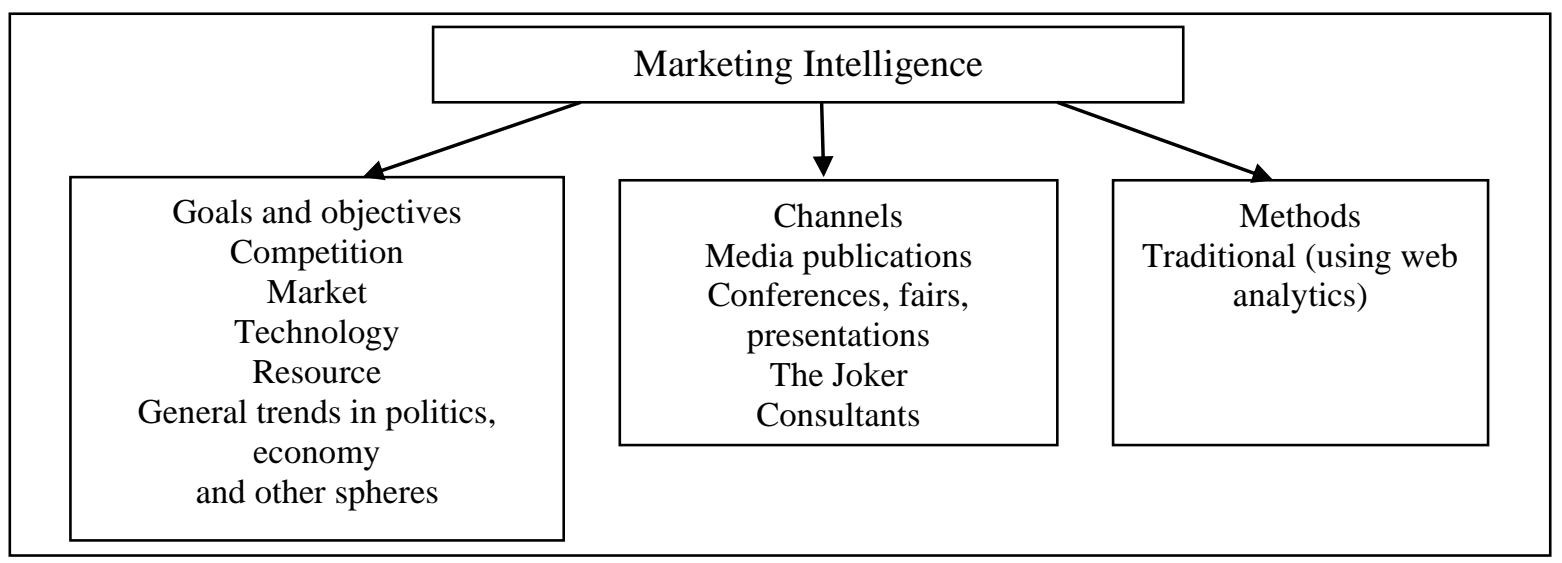

Fig. 1. Goals, Channels, and Methods of Marketing Intelligence.*

* Source: Development by Authors' [1]

The real methods of obtaining marketing information during marketing intelligence are: collecting open documentary information from advertising, scientific and general publications, etc.; during exhibitions and presentations, at various conferences; visits to competitors under the guise of ordinary clients; audit of competitors' outlets; using the results of competitor studies obtained by different methods, etc. Those methods can be used to obtain information of two types: legal (open source) and confidential (one that is not publicly available and which is often obtained through covert surveillance and economic espionage) [1].

Today, many companies have departments dedicated to the collection and processing of intelligence. The employees of these departments are engaged in all of the above activities. It is quite understandable that the high efficiency of these departments is high. For example, in Japan, marketing intelligence is part of the company's culture. Each employee deems it necessary to provide management with all information about competitors. That is why businesses create cafes for their workers so they don't accidentally share a commercial secret. It also has to take considering marketing counterintelligence to protect the firm's information from competitors. Even custom lists are created that capture information related to «borrowing» from other technology firms, know-how, and more. These lists assist in litigation with competitors [1].

An example of how companies today conduct marketing intelligence is the activities of large companies such as Google, Facebook, Microsoft and more. Google recently introduced a high-tech Google Analytics solution [15]. With this web analytics system, let's look at how marketing intelligence can work today.

Google Analytics allows you to collect statistics about user behavior on the site and to generate analytics based on the data obtained. With Google Analytics, you can track attendance, conversion, and revenue for online promotion, explore issues and manage and manage your online campaigns more effectively. Fig. 2 shows a simplified Google Analytics algorithm.

Site visitors (users) download the company website. The program writes a visitor to the browser (creates a cookie). Assigns a unique Client ID). For the second (and subsequent) visits, a Google Analytics user counts as a repeat visit. But since in the mobile age, a potential customer can access the site in the morning from their smartphone, in the daytime from a computer, and in the evening from a tablet (and such a sequence can be recorded as three visits, made by not one but three users), to address this deficiency, Google Analytics provides a custom parameter, the User ID, which identifies the user by their email address or login. Google Analytics settings are shown in the table below.

Based on cookie data, Google Analytics lets you generate audience reports based primarily on demographics, interests, locations, new users and returning visitors, frequency and time of the last visit, and mobile browsing reports for users on the way and others. Such an audit allows you to see the weaknesses of the site. Obtain interim data and draw definitive conclusions about the performance of certain developments. The information obtained will be useful for studying and interpreting the main reports. Yes, the demographic report includes user characteristics such as age, gender, interests. Specifically, the program allows you to segment your audience by interests, such as "food," "other categories," etc. 


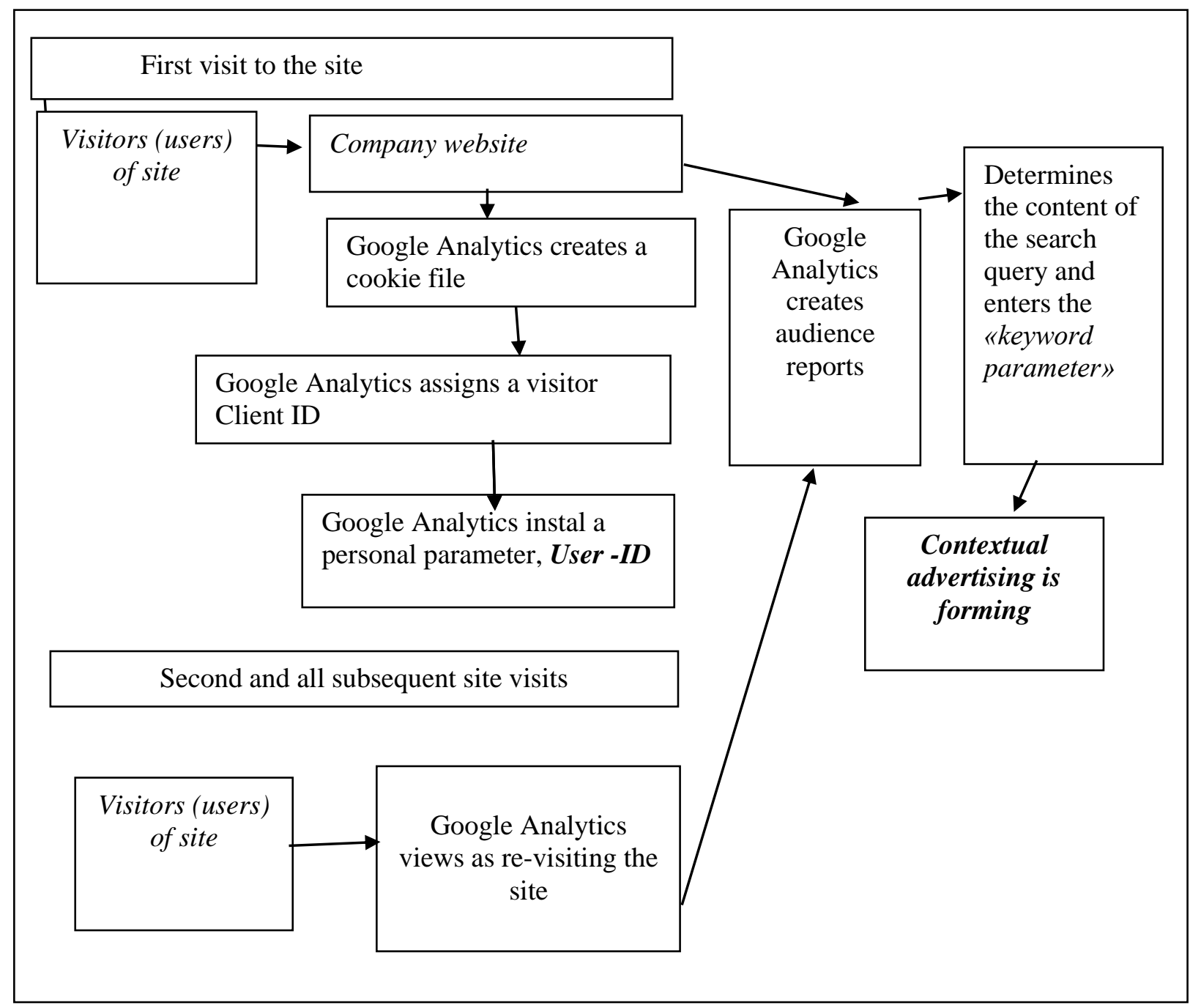

Fig. 2. A neat diagram of how Google Analytics works.

Source: Development by Authors' [15]

The geography report page shows a map of the world, and by clicking on the map you can specify statistics about where the user is located in which country or city. The Behavior report provides an opportunity to get consumer information by categories such as user type: new and returning, that is, visitors who have been to this site before. Also, this program allows you to estimate the depth of page views (the number of pages viewed), as well as the frequency and time since the last visit.

Table 1

Paramiters of Google Analytics

\begin{tabular}{|l|l|}
\hline Paramiters & \multicolumn{1}{|c|}{ Characteristic } \\
\hline Session & Attendance, session, visit \\
\hline Users & People who visit the site \\
\hline Depth of view & The ratio of pageviews to the number of sessions \\
\hline Average Session Duration & $\begin{array}{l}\text { Defined as the ratio of the length of sessions to the } \\
\text { number of sessions }\end{array}$ \\
\hline Bounce rate & \% of sessions in which only one page was viewed \\
\hline Percentage of new sessions & $\begin{array}{l}\text { Shows the share of sessions of new users (facts about } \\
\text { the creation of new cookies) }\end{array}$ \\
\hline
\end{tabular}

Source: [15] 
Also, Google Analytics analyzes the referent, determines the content of the search query and places it in the Keyword parameter. You can go to the Traffic Source - Campaigns - Unpaid Keywords tab to see a restricted search keyword report. This is the basis for the formation of effective contextual advertising.

Despite the obvious benefits to site owners of using this program, there are several ethical issues. Yes, Facebook mostly uses methods similar to those used by Google [2]. However, it should be noted that this service integrates with other sites. When browsing the site, while reading various news articles or articles, you can often see a "share to facebook" button on the page. This button indicates that this site is integrated with Facebook, and presumably, visitor data to a specific user went to the company's servers. However, there are unpleasant rumors about the company. Mobile users noticed that when they talked to someone about certain topics near their phones, such as dog food, they saw advertisements for that feed over some time, even though they never bought dogs or feed.

Different moments of Facebook's activity have led to the emergence of Stop using Facebook, which stores link to articles on popular services describing unpleasant moments for the company [8]. For example, there is a link to a New York Times article dated December 18, 2018, stating that a company discloses personal information to other companies [9].

As far as Microsoft is concerned, it releases the most popular PC operating system on Windows. With the release of Windows 10 , users have noticed that it has added "telemetry" - sending certain data to Microsoft servers for better personalization of advertising, but when you install the system there is an opportunity to partially disable it. This "spying" led to the emergence of special programs designed to disable telemetry [10]. It should be noted that the company has created a service [5], which can view all the data that the company received by the EU legislation, but we can not be sure that the company does not hide anything.

You should also note that some companies obtain information through the use of software vulnerabilities or access to the phone's system services. Also, users of devices such as, for example, iPhone are not immune to these problems. Recently, Tech Crunch conducted a study [4], which found that many applications recorded phone screens without even informing users. Apple company, on whose devices the recording was made, confirmed this information, noting that they knew about the possibility, but left it to applications only for use in good faith and asked developers to remove the code from the programs that allow it to do so [5].

Collecting data by organizations, corporations, and businesses also create additional issues beyond the uncontrolled use and resale of user data. A significant problem is their insecure storage and frequent "draining" of data of users of different services. For example, in early 2019, nearly 50 million Instagram users were discovered on Indian servers. The most interesting thing is that the data was collected by Chtrbox, which most victims did not even know existed. The information in the databases also contained user e-mail addresses and significant amounts of other information and was intended to estimate the cost of advertising on each of the accounts [11]. Google recently confirmed that its employees listened to audio files recorded using Google Home smart speakers. Shortly before, the journalists of the Belgian VRT NWS were able to obtain and listen to more than a thousand recordings made with the help of Google Voice Assistant. This helped them find the column owners fairly quickly, even though the records were anonymized. According to Google, they have been used to improve speech recognition algorithms with artificial intelligence. [8]. There is also the question of marketing intelligence in the wake of the increasing popularity of Smart Home systems. In most cases, all the data goes through the servers of a particular company, which allows you to get a variety of information from what interests the person on the Internet, which prefers dishes, how much time it takes to study various matters before being able to connect to a variety of equipment with subsequent constant listening conversations. The development of 5G networks will only facilitate the rapid transmission of large amounts of data. Besides, access to devices by the company will also mean the ability to control devices to hackers. The average consumer will be in a situation where the «reasonable door» will not want to let him out of the apartment until the ransom is paid.

There are also scandals in the territory of Ukraine about poorly protected databases or the complete lack of their protection. For example, on May 22, 2018, it was discovered that the Automated Troop Management System was protected by standard passwords. Despite repeated warnings about the danger of this situation, passwords have not been changed for several months [12]. If data security indifference is possible in the military field, where there is ongoing monitoring, then there is a high likelihood of such 
situations on the servers of companies that collect user data. Today, it is hard to surprise anyone that after purchasing a new SIM card after a short period, people begin to receive promotional messages, invitations to attend a concert or attend a meeting with a candidate from a political party before the election. This is further evidence of the ongoing sale of data.

Also, constant data collection during marketing intelligence creates other problems:

- unfair use. The offender can easily gain access to certain information about a person for further use in blackmail with a ransom demand;

- secrets outside. Sometimes it is easy to get information about a person simply by opening their browser. A person can have AIDS and hide this information from others, but someone from a friend or work colleague can find out the secret through drug advertising. This will have negative consequences. If you talk about some Muslim countries, they can be sentenced to death there because of sexual orientation.

This almost unregulated situation could not be left without the appropriate reaction of the governments of different countries. In particular, on 25 May 2018, the General Data Protection Regulation (GDPR) adopted in the European Union [13]. It aims to enable EU citizens to control their data.

One of the results of this regulation is that most services are forced to allow the user to download and view information stored by a particular service. A positive consequence is that many services are open to all users, regardless of the country. However, this regulation does not allow users to force services to delete certain information about them. There is also a likelihood that organizations may hide certain information.

Also, large companies are trying to create opportunities for collecting and processing personal data of users without breaching privacy. For example, on June 19, 2019, Google introduced the Private Join and Compute cryptographic protocol, which allows you to analyze a private database without being able to view a specific value using special encryption methods [15]. A significant advantage of this solution is its placement under a free license, which allows everyone the opportunity to modify and use this protocol for free.

It should be noted that the issue of uncontrolled use of data about users of services on the Internet is not new. One of the first to predict this problem was predicted by Richard Stallman, an American programmer, an activist of free software [14]. It is worth noting that he also suggested a solution to this issue, which was that everyone would be able to view the code of the programs he used and, if desired, change. In our opinion, his proposal can help with the uncontrolled use of user data, but there are significant problems with its implementation, as it will be able to deprive most companies of a large part of the profits and make it impossible to conduct marketing intelligence using modern technology as it is today.

Conclusions and prospects for further research. Marketing intelligence is necessary to develop and adjust a company's marketing plan and to anticipate future changes. Today, with specially designed applications, including Google Analytics, you can see the effectiveness and results of marketing intelligence at a minimal cost. Unfortunately, nowadays, marketing intelligence is often carried out using commercial and industrial espionage, which is the cause of moral and legal problems. Besides, there is a significant problem with storing and processing large amounts of data obtained through marketing intelligence. Also, the use of marketing intelligence in some countries can harm the social status (and sometimes life) of consumers.

Today, some measures are underway in the world to control the exchange, storage, and processing of information about people, but the high inertia of the legislative bodies of the countries impedes the rapid and timely implementation of the necessary bills. The positive thing is the start of the development of secure and open methods of processing private data of users without their direct identification by large companies. The prospect of further research should be to develop a legal framework and rules that will limit interference on people's privacy. Keep marketing research possible without affecting people's lives.

\section{Sources and literature}

1) Полторак В. А. Маркетингові дослідження: навч. посіб. / В. А. Полторак, І. В. Тараненко, О. Ю. Красовська [Електронний ресурс]. - Режим доступу: https://pidruchniki.com/1281041960644/marketing/marketingova_rozvidka_tsili_dzherela_metodi_oderzhannya_infor matsiyi.

2) How Ads Work on Facebook [Електронний ресурс]. - Режим доступу: https://www.facebook.com/help/516147308587266/?helpref=hc_fnav 
3) Whittaker Z. Many popular iPhone apps secretly record your screen without asking [Електронний ресурc]. Режим доступу: https://techcrunch.com/2019/02/06/iphone-session-replay-screenshots/

4) Whittaker Z. Apple tells app developers to disclose or remove screen recording code [Електронний ресурс]. Режим доступу: https://techcrunch.com/2019/02/07/apple-glassbox-apps/

5) Diagnostic Data Viewer [Електронний ресурс]. - Режим доступу: https://www.microsoft.com/enus/p/diagnostic-data-viewer/9n8wtrrsq8f7?activetab=pivot\%3Aoverviewtab

6) Chrome extension manifest v3 proposal \#338 [Електронний ресурс]. - Режим доступу: https://github.com/uBlockOrigin/uBlock-issues/issues/338r/degoogle [Електронний ресурс]. - Режим доступу: https://www.reddit.com/r/degoogle/

7) Stop using Facebook [Електронний ресурс]. - Режим доступу: https://www.stopusingfacebook.co/

8) Dance G. J.X., LaForgia M. and Confessore N.. As Facebook Raised a Privacy Wall, It Carved an Opening for Tech Giants [Електронний ресурс]. - Режим доступу: https://www.nytimes.com/2018/12/18/technology/facebookprivacy.html

9) O\&O ShutUp10: Free antispy tool for Windows 10 [Електронний ресурс]. - Режим доступу: https://www.oo-software.com/en/shutup10

10)Whittaker Z. Millions of Instagram influencers had their contact data scraped and exposed [Електронний pecypc]. - Режим доступу: https://techcrunch.com/2019/05/20/instagram-influencer-celebrity-accountsscraped/ ?guccounter $=$ aHR0cHM6Ly93d3cuYmJjLmNvLnVrL25ld3Mvd29ybGQtYXNpYS1pbmRpYS00ODM0NzU5Mg\&guce referrer_c s=25bHLb1hTJkNKXwlKGYafQ

11)Скандал у ЗСУ: система управління військами виявилася «захищена» примітивними паролями типу «Admin» i «123456» [Електронний ресурс]. - Режим доступу: https://www.unian.ua/politics/10274616-skandal-uzsu-sistema-upravlinnya-viyskami-viyavilasya-zahishchena-primitivnimi-parolyami-tipu-admin-i-123456.html

12)General Data Protection Regulation (GDPR) [Електронний ресурc]. - Режим доступу: https://gdpr-info.eu/

13)Stallman R. Keep control of your computing, so it doesn't control you! [Електронний ресурс]. - Режим доступу: https:// web.archive.org /web/ 20111226225337/ https:// www.gnu.org /philosophy/keep-control-of-yourcomputing.en.html

14)Google открыл систему для анализа наборов данных без нарушения конфиденциальности [Електронний ресурс]. - Режим доступу: https://www.opennet.ru/opennews/art.shtml?num=50915

15)Google Analytics.Подробное практическое руководство. -Бесплатное электронное издание ООО »Ингейт-реклама», 2016. [Електронний ресурс]. - Режим доступу: https://ktonanovenkogo.ru/vokrug-daokolo/schetchiki/hovaya-kniga-google-analytics-podrobnoe-prakticheskoe-rukovodstvo.html

16)Хант Ч. Разведка на службе вашего предприятия / Ч. Хант, В. Зартарьян - К.: Укрзакордонвизасервис, 1992. $-160 \mathrm{c}$.

\section{References}

1. Poltorak V. A., Taranenko I. V., Krasovskaya O. Yu.. Marketynhovi doslidzhennia [Marketing researches] Retrieved from https://pidruchniki.com/1281041960644/marketing/marketingova_rozvidka_tsili_dzherela_metodi_oderzhannya_infor matsiyi. [ in Ukrainian].
2. How
Ads
Work
on
Facebook
Retrieved
from

https://www.facebook.com/help/516147308587266/?helpref=hc_fnav[in English].

3. Whittaker Z. Many popular iPhone apps secretly record your screen without asking - Retrieved from https://techcrunch.com/2019/02/06/iphone-session-replay-screenshots/[in English].

4. Whittaker Z. Apple tells app developers to disclose or remove screen recording code - Retrieved from https://techcrunch.com/2019/02/07/apple-glassbox-apps/[in English

5. Diagnostic Data Viewer - Retrieved from https://www.microsoft.com/en-us/p/diagnostic-dataviewer/9n8wtrrsq8f7? activetab=pivot\%3Aoverviewtab [in English].

6. Chrome extension manifest v3 proposal \#338 - Retrieved from https://github.com/uBlockOrigin/uBlockissues/issues/338[in English].r/degoogle - Retrieved from https://www.reddit.com/r/degoogle/[in English].

7. Stop using Facebook - Retrieved from https://www.stopusingfacebook.co/[in English].

8. Dance G. J.X., LaForgia M. and Confessore N.. As Facebook Raised a Privacy Wall, It Carved an Opening for Tech Giants- Retrieved from https://www.nytimes.com/2018/12/18/technology/facebook-privacy.html[in English

9. Zack Whittaker. O\&O ShutUp10: Free antispy tool for Windows 10 - Retrieved from https://www.oosoftware.com/en/shutup10[in English]. 
10. Millions of Instagram influencers had their contact data scraped and exposed - Retrieved from https://techcrunch.com/2019/05/20/instagram-influencer-celebrity-accounts-

scraped/?guccounter=1\&guce_referrer_us=aHR0cHM6Ly93d3cuYmJjLmNvLnVrL25ld3Mvd29ybGQtYXNpYS1pbm RpYS00ODM0NzU5Mg\&guce_referrer_cs=25bHLb1hTJkNKXwlKGYafQ[in English].

11. Skandal u ZSU: systema upravlinnia viiskamy vyiavylasia «zakhyshchena» prymityvnymy paroliamy typu «Admin» i «123456» [Armed Forces Scandal: Troops Management System Has Been Protected by Admin and 123456 Primitive Passwords] - Retrieved from https://www.unian.ua/politics/10274616-skandal-u-zsu-sistema-upravlinnyaviyskami-viyavilasya-zahishchena-primitivnimi-parolyami-tipu-admin-i-123456.html[in Ukrainian].

12. General Data Protection Regulation (GDPR) - Retrieved from https://gdpr-info.eu/[in English].

13. Stallman R. Keep control of your computing, so it doesn't control you! - Retrieved from https://web.archive.org/web/20111226225337/https://www.gnu.org/philosophy/keep-control-of-yourcomputing.en.html[in English].

14. Google otkrыl systemu dlia analyza naborov dannыkh bez narushenyia konfydentsyalnosty [Google has opened a system for analyzing datasets without compromising privacy] - Retrieved from https://www.opennet.ru/opennews/art.shtml?num=50915[in Russian].

15. Google Analytics. Podrobnoe praktycheskoe rukovodstvo Подробное практическое руководство (2016). [Detailed practical guide] - Retrieved from https://ktonanovenkogo.ru/vokrug-da-okolo/schetchiki/hovaya-knigagoogle-analytics-podrobnoe-prakticheskoe-rukovodstvo.html [in Russian].

16. Hunt Ch., Zartaryan V. Razvedka na sluzhbe vasheho predpryiatyia [Intelligence at the service of your business].(1992). Ukrzakordonvyzaservys Kyiv, Ukraine.

Стаття надійшла до редакції 20.11.2019 р.

УДК: 338.432 .5

Філюк Дмитро, аспірант,

Східносвропейський національний університет імені Лесі Українки, кафедра обліку та аудиту,

м. Луцьк ORCID ID 0000-0002-2678-3424 e-mail:0666763009@ukr.net

\author{
https://doi.org/10.29038/2411-4014-2019-04-124-132
}

\title{
СЕЛЕКЦІЯ - ВАЖЛИВА СКЛАДОВА ЗРОСТАННЯ ЕКОНОМІЧНОГО ПОТЕНЦІАЛУ БДЖІЛЬНИЦТВА
}

У статті проаналізовано ситуацію у сфері селекційної діяльності в Україні та розглянута роль селекції в збільшенні виробничої продуктивності бджологосподарств. Розкриті досягнення, проблеми і завдання селекції на сучасному рівні розвитку сільськогосподарського виробництва. Доведено, що селекція найдешевший, найрезультативніший та екологічно чистий чинник зростання виробництва продукції тваринництва. Визначено пріоритети стратегій і планів дій щодо генетичних ресурсів для виробництва продовольства і ведення сільського господарства. Відмічено, що реальні можливості сільського господарства України, зокрема бджільництва, задля зростання економічної ефективності та конкурентоспроможності галузі повинні складатися із найважливіших чинників які необхідно реалізовувати за допомогою розроблення загальнодержавної стратегії ефективних програм селекції. Запропоновано напрями i заходи щодо стимулювання розвитку селекції в контексті підвищення економічної ефективності бджільництва.

Ключові слова: порода, генетичні ресурси, селекція, селекційна діяльність, племінна робота, ефективність, продуктивність, оцінка продуктивності. 